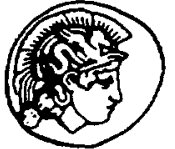

PERGAMON

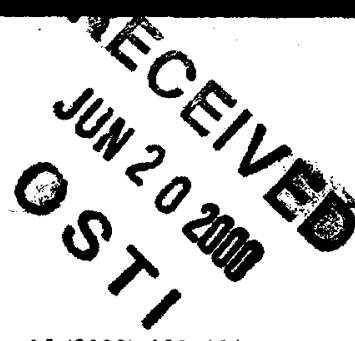

Applied Geochemistry 15 (2000) 655-666
SAND2000-1413J

\section{Applied \\ Geochemistry}

\title{
A process model of natural attenuation in drainage from a historic mining district
}

\author{
Amy C. Berger $^{\mathrm{a}, *}$, Craig M. Bethke ${ }^{\mathrm{a}}$, James L. Krumhansl ${ }^{\mathrm{b}}$ \\ aDepartment of Geology, University of Illinois Urbana-Champaign, I30I W. Green St., Urbana, IL 61801, USA \\ ${ }^{b}$ Geochemistry Division, Sandia National Laboratories, Albuquerque, NM 87185-0750. USA
}

Received 14 December 1998; accepted 22 June 1999

Editorial handling by $C$. Reimann

Abstract

A process model was used to better understand the controls on the chemical evolution of drainage in a historic mining district. At the Pecos Mine Operable Unit, New Mexico, drainage near the waste rock pile is acidic ( $\mathrm{pH}$ varies from 3.0-5.0) and carries high concentrations of $\mathrm{Zn}, \mathrm{Al}, \mathrm{Cu}$ and $\mathrm{Pb}$. As drainage flows toward the Pecos River, $\mathrm{pH}$ increases to greater than 7 and heavy metal content decreases. A process model of natural attenuation in this drainage shows the main controls on $\mathrm{pH}$ are reaction with a local bedrock that contains limestone, and concurrent mixing with tributary streams. Models that account for both calcite dissolution and mixing reproduce the observed decrease in aqueous metal concentrations with increasing $\mathrm{pH}$. Contaminant concentrations attenuate primarily via two distinct pathways: $\mathrm{Al}, \mathrm{Cu}, \mathrm{Fe}$ and $\mathrm{Pb}$ precipitate directly from solution, whereas $\mathrm{Zn}, \mathrm{Mg}, \mathrm{Mn}$ and $\mathrm{SO}_{4}$ concentrations decrease primarily through dilution. Additionally, $\mathrm{Pb}$ adsorbs to precipitating hydroxide surfaces. (c) 2000 Published by Elsevier Science Ltd. All rights reserved.

\section{Introduction}

Acid drainage from metal mining districts is a wellrecognized source of environmental contamination (Förstner and Wittman, 1981; Kelly, 1988). Oxidation of metal sulfides in mines, mine dumps, and tailings impoundments produces acidic, metal-rich waters that can contaminate local surface water and groundwater. Acidic waters are toxic to fish, flora and aquatic insects. Heavy metals carried by mine drainage into the surrounding environment interfere with aquatic

* Corresponding author. Present address: Heidelberg College, Tiffin, OH 44883. USA.

E-mail address: aberger@mail.heidelberg.edu (A.C. Berger). ecosystems. In addition, acid drainage can threaten drinking water supplies and irrigation systems downstream from mining sites.

Many factors affect the chemistry of mine drainage. The initial chemistry depends on a variety of geological and geochemical controls, including the type and abundance of metal-bearing sulfides in ore and wall rock, kinetic rates of ore and wall rock dissolution, permeability of the ore deposit or mine tailings, and the ability of the host rock to buffer acidity (Plumlee et al., 1992; Strömberg and Banwart, 1994).

In some cases, particularly where host rock is capable of buffering drainage, metal content attenuates to background concentrations before drainage leaves the mine site. A primary control on the process of metal attenuation is acid neutralization. Neutralization can occur where the drainage encounters rock of high 


\section{DISCLAIMER}

This report was prepared as an account of work sponsored by an agency of the United States Government. Neither the United States Government nor any agency thereof, nor any of their employees, make any warranty, express or implied, or assumes any legal liability or responsibility for the accuracy, completeness, or usefulness of any information, apparatus, product, or process disclosed, or represents that its use would not infringe privately owned rights. Reference herein to any specific commercial product, process, or service by trade name, trademark, manufacturer, or otherwise does not necessarily constitute or imply its endorsement, recommendation, or favoring by the United States Government or any agency thereof. The views and opinions of authors expressed herein do not necessarily state or reflect those of the United States Government or any agency thereof. 


\section{DISCLAIMER}

Portions of this document may be illegible in electronic image products. Images are produced from the best available original document. 


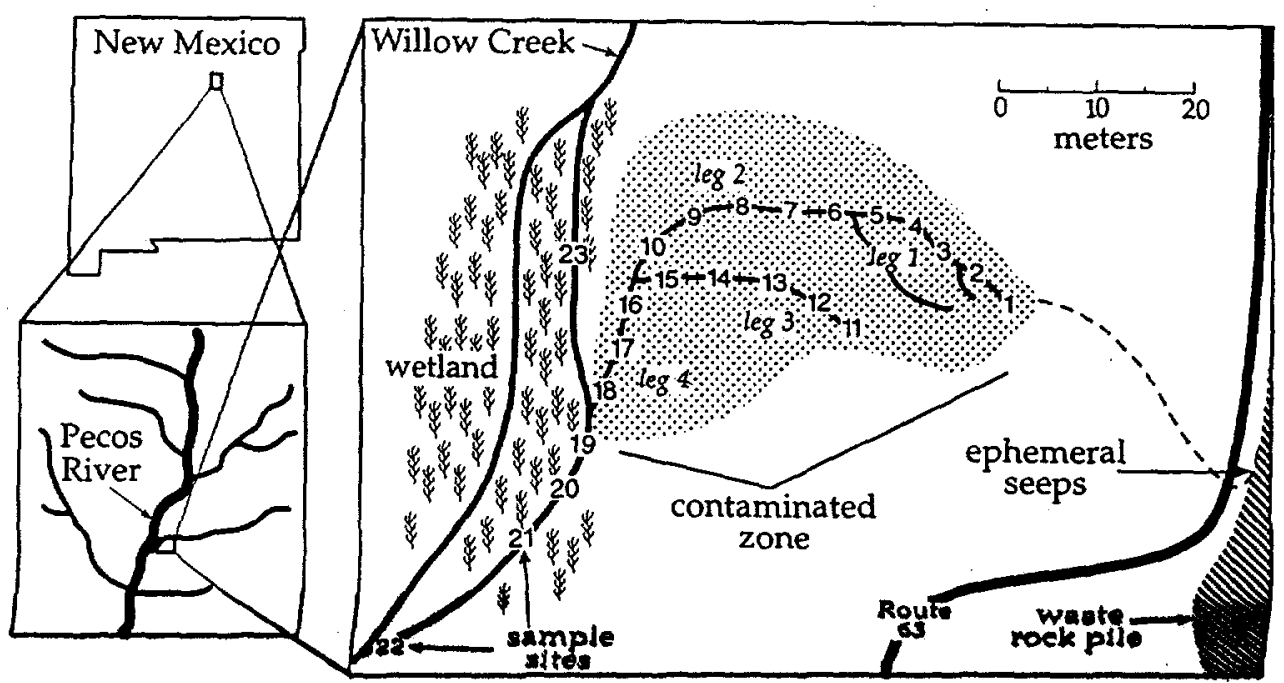

Fig. 1. Contaminated drainage at the Pecos Mine Operable Unit. Numbers indicate sample sites ajong the drainage pathway: sites $1-5=\operatorname{leg} 1$, sites $6-10=\operatorname{leg} 2$. sites $11-15=\operatorname{leg} 3$. sites $16-22=\operatorname{leg} 4$

buffering capacity, when $\mathrm{CO}_{2}$ degasses, and where drainage mixes with ambient waters (Chapman et al., 1983). As pH increases, aqueous metal species tend to precipitate as hydroxide, oxyhydroxide, or hydroxysulfate phases (Kimball et al., 1994). Metals may also adsorb onto surfaces of these newly formed precipitates, removing the metals from solution (Nordstrom, 1982; Chapman et al., 1983). As well, simple dilution can attenuate metal concentration, independent of chemical reaction.

To develop an effective remediation strategy, it is important to understand how these factors affect drainage chemistry. In this study, the authors present a quantitative model of the processes responsible for acid neutralization and metal attenuation in mine drainage. The Pecos Mine Operable Unit provides a natural laboratory for studying drainage chemistry: the drainage is initially acidic and rich in metals, but over a short distance the drainage $\mathrm{pH}$ increases and metal concentrations approach levels observed in pristine areas.

\section{Description of study area}

The Pecos Mine Operable Unit, located in the southern Sangre de Cristo mountains in New Mexico (Fig. 1), produced $\mathrm{Cu}-\mathrm{Pb}-\mathrm{Zn}$ ore intermittently from

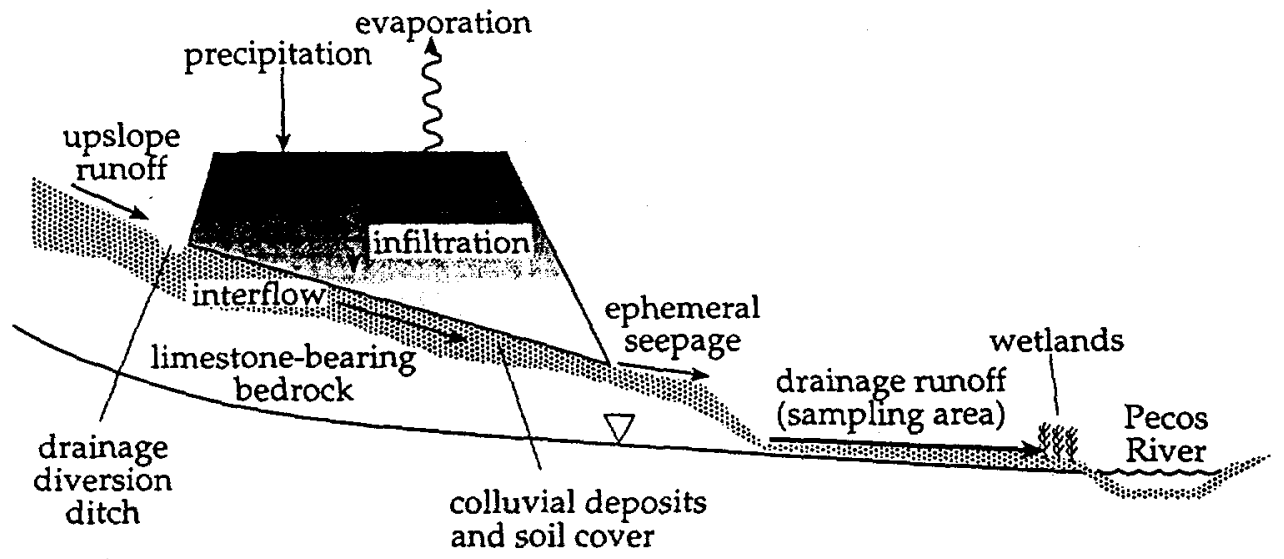

Fig. 2. Conceptual model of drainage through the waste rock pile and to the Pecos River (modified from Sioller. 1994). Triangle marks position of the water table. Figure not to scale. 
1881 to 1939 . Waste rock from mining operations was deposited in a pile on top of a preexisting drainage channel, and covers about $0.077 \mathrm{~km}^{2}$. An aerial tramway carried ore to a nearby processing mill. Mill tailings were deposited at the processing site, which has undergone remediation by containment and burial (Stoller, 1994).

The waste rock pile was deposited on top of a section of a Pennsylvanian age sedimentary conglomeratic unit consisting of siliciclastic and limestone material (Stoller, 1993). Lithologically, the waste rock is dominated by quartz-chlorite and biotite schists (Stoller, 1993) typical of the subsurface metamorphosed shear zone that hosts the ore bodies (Krieger, 1932; Riesmeyer and Robertson, 1979). The waste rock pile contains about $2550 \mathrm{~m}^{3}$ of heterogeneous material (Stoller, 1994), with clasts ranging in size from fine sand to boulders.

Observation wells installed within the pile indicate it is largely unsaturated and that the water table lies below the base of the pile (Fig. 2). Flow through the dump is primarily vertical (Stoller, 1993). Within the dump, atmospheric $\mathrm{O}_{2}$ reacts in the presence of rainwater to dissolve metal sulfides, producing acid and adding heavy metals to solution. Ephemeral seeps drain the resulting acidic, metal-rich water from the base of the dump at several points. Continual contaminated flow emerges from seeps downslope from the dump, amid limestone cobbles and boulders from the underlying conglomerate.

Drainage from the seeps has killed about $500 \mathrm{~m}^{2}$ of wetland flora. It flows toward the Pecos River in shallow channels (about $3-5 \mathrm{~cm}$ in depth) that overflow during rain events. A branch of Willow Creek, which drains regions north of the contaminated zone, joins the drainage after site 18 (Fig. 1). The mixed drainage then flows into the Pecos River about $80 \mathrm{~km}$ south of the river's headwaters. The river is a significant water source for eastern New Mexico, a predominantly agricultural area. As part of the Pecos State Forest, portions of the river downstream of the mine are used for recreational fishing, and a fish hatchery is located 23 $\mathrm{km}$ south of the Pecos Mine Operable Unit.

Contaminated drainage comes into direct contact

Table 1

Aqueous concentrations $(\mathrm{mg} / \mathrm{l})$ of filtered samples from the Pecos Mine Operable Unit drainage. Distance is measured upstream from site 22. Figure I shows sample locations

\begin{tabular}{|c|c|c|c|c|c|c|c|c|c|c|c|c|c|c|c|c|}
\hline & $\begin{array}{l}\text { Sample } \\
\text { number }\end{array}$ & $\begin{array}{l}\text { Distance } \\
(\mathrm{m})\end{array}$ & $\mathrm{pH}$ & $\begin{array}{l}\mathrm{O}_{2} \\
(\mathrm{aq})\end{array}$ & $\mathrm{Zn}$ & $\mathrm{SO}_{4}$ & $\mathrm{Mg}$ & $\mathrm{Ca}$ & $\mathrm{Al}$ & $\mathrm{Cl}$ & $\mathrm{Cu}$ & $\mathrm{Mn}$ & Total $\mathrm{Fe}$ & $\mathrm{Fe}^{++}$ & $\mathrm{Fe}^{+++}$ & $\mathrm{Pb}$ \\
\hline \multirow[t]{5}{*}{ Leg 1} & 1 & 77.7 & 4.1 & 10 & 2211 & 8120 & 538 & 441 & 105.80 & 68.4 & 22.41 & 14.79 & 0.82 & 0.00 & 0.82 & 0.41 \\
\hline & 2 & 74.7 & 4.7 & & 1048 & 4250 & 281 & 356 & 20.45 & 58.8 & 10.65 & 10.40 & 0.87 & 0.61 & 0.26 & 0.21 \\
\hline & 3 & 71.6 & 4.8 & & 897 & 4240 & 296 & 267 & 16.56 & 52.5 & 10.88 & 3.86 & 2.00 & 1.14 & 0.86 & 0.24 \\
\hline & 4 & 68.6 & 5.3 & & 568 & 2110 & 138 & 151 & 4.59 & 33.6 & 5.28 & 6.87 & 1.46 & 1.28 & 0.18 & 0.06 \\
\hline & 5 & 65.5 & 5.5 & 5 & 681 & 2480 & 185 & 270 & 1.02 & 37.3 & 1.44 & 6.90 & 1.17 & 0.84 & 0.33 & 0.01 \\
\hline \multirow[t]{5}{*}{ Leg 2} & 6 & 62.5 & 4.7 & & 568 & 5110 & 138 & 151 & 4.59 & 53.7 & 5.28 & 6.87 & 1.46 & 0.43 & 1.03 & 0.06 \\
\hline & 7 & 59.4 & 4.7 & & 1435 & 5210 & 363 & 382 & 48.55 & 54.1 & 13.75 & 11.54 & 1.05 & 0.39 & 0.66 & 0.34 \\
\hline & 8 & 56.4 & 4.7 & & 1210 & 4550 & 322 & 354 & 36.73 & 49.8 & 11.13 & 11.19 & 0.93 & 0.47 & 0.46 & 0.40 \\
\hline & 9 & 53.3 & 4.7 & & 1239 & 4540 & 318 & 355 & 33.78 & 49.7 & 10.66 & 11.39 & 0.91 & 0.41 & 0.50 & 0.38 \\
\hline & 10 & 50.3 & 4.7 & & 1269 & 4750 & 318 & 355 & 33.78 & 50.7 & 10.66 & 11.39 & 0.91 & 0.42 & 0.49 & 0.38 \\
\hline \multirow[t]{5}{*}{ Leg 3} & 11 & 70.1 & 4.2 & 10 & 1752 & 6260 & 448 & 509 & 93.79 & 53.70 & 18.83 & 16.17 & 1.35 & 0.02 & 1.34 & 0.20 \\
\hline & 12 & 65.5 & 4.5 & & 1232 & 4320 & 308 & 388 & 44.64 & 42.00 & 13.01 & 12.58 & 1.94 & 0.87 & 1.07 & 0.10 \\
\hline & 13 & 61.0 & 5.8 & & 476 & 2120 & 117 & 298 & 0.1 & 21.70 & 0.23 & 7.43 & 0.23 & 0.13 & 0.10 & 0.00 \\
\hline & 14 & 57.9 & 5.6 & & 411 & 1990 & 169 & 296 & 1.54 & 21.10 & 1.73 & 7.37 & 2.63 & 2.47 & 0.16 & 0.05 \\
\hline & 15 & 53.3 & 5.3 & & 581 & & 195 & 313 & 4.85 & & 4.45 & 7.89 & 2.30 & 2.37 & 0.00 & 0.18 \\
\hline \multirow[t]{7}{*}{ Leg 4} & 16 & 47.2 & 4.5 & 6 & 1138 & 4280 & 283 & 363 & 33.35 & 42.70 & 10.67 & 10.75 & 2.24 & 1.32 & 0.92 & 0.49 \\
\hline & 17 & 44.2 & 4.8 & & 929 & 3510 & 254 & 322 & 18.00 & 36.40 & 9.52 & 9.36 & 3.13 & 2.27 & 0.86 & 0.44 \\
\hline & 18 & 41.1 & 4.9 & & 893 & 3380 & 252 & 314 & 16.00 & 35.80 & 9.98 & 9.32 & 3.05 & 2.33 & 0.72 & 0.46 \\
\hline & 19 & 37.5 & 5.8 & 6 & 448 & 2140 & 141 & 224 & 1.49 & 23.80 & 3.06 & 4.99 & 3.68 & 3.66 & 0.02 & 0.03 \\
\hline & 20 & 35.1 & 5.9 & & 516 & 2020 & 141 & 238 & 1,48 & 23.70 & 2.94 & 5.22 & 2.85 & 2.75 & 0.10 & 0.05 \\
\hline & 21 & 30.5 & 6.0 & & 447 & 1710 & 129 & 221 & 0.74 & 20.90 & 1.98 & 4.79 & 1.95 & 1.60 & 0.35 & 0.02 \\
\hline & 22 & 0.0 & 7.2 & & 135 & 603 & 59 & 127 & 0.13 & 9.20 & 0.39 & 1.74 & 0.04 & 0.00 & 0.04 & 0.01 \\
\hline Willow Creek & 23 & 55.5 & 7.2 & 3 & 3 & 119 & 26 & 41 & 0.00 & 9.30 & 0.01 & 4.00 & 7.68 & 6.82 & 1.86 & 0.00 \\
\hline
\end{tabular}


with limestone in the underlying formation in the vicinity of the seeps. The limestone shows evidence of dissolution: it is cracked and discolored compared to limestone unaffected by the drainage. A soil layer increasingly covers the limestone with increasing distance from the seeps.

Water from unmined areas flows down gradient (south) over and through saturated soils, mixing with drainage water at sites 3-10 and 13-18 (Fig. 1). Near the seeps, a red precipitate coats the drainage channels. A white to blue gelatinous precipitate forms as the drainage flows away from the seeps, immediately downstream from the red precipitate. This white precipitate is particularly abundant at sites where the drainage appears to either mix with background water or react with limestone. Limestone is well exposed near the seeps. In these areas, drainage appears to mix concurrently with background waters and react with the underlying bedrock.

\section{Methodology}

Surface drainage was sampled from the seeps to beyond the confluence of the mine drainage with Willow Creek in August, 1996 (Fig. 1). Groups of samples were taken from sites spaced 3-4 m apart. At each site, temperature and $\mathrm{pH}$ were recorded and samples were stored in acid washed $60 \mathrm{ml} \mathrm{HDPE}$ bottles. The first 3 samples were filtered using a pre-rinsed Nalgene filter holder with a receiver connected to a hand vacuum pump, mounted with a $0.1 \mu \mathrm{m}$ Gelman filter. One sample, intended for major cation analysis, was acidified with $\mathrm{HNO}_{3}$ to a $\mathrm{pH}$ of $<1.5$. The second sample was acidified with $\mathrm{HCl}$ to allow the distribution of $\mathrm{Fe}$ between Fe(II) and Fe(III) species to be determined. The third filtered sample was left unacidified for anion analysis. Filters from these 3 samples were saved for $\mathrm{X}$-ray diffraction analysis of the solid material. Samples were placed on ice for transport to the laboratory and refrigerated until analyzed. In addition, dissolved $\mathrm{O}_{2}$ content was measured at several sites using a CHEMmets ${ }^{\text {it: }}$ kit.

Concentrations of major cations, anions, and $\mathrm{Fe}$ redox distribution were determined in the lab 3 weeks after sampling. Cation concentrations were determined by inductively coupled plasma spectrometry. Anion contents were analyzed by ion chromatography. Iro$\mathrm{n}$ (II) concentrations were determined colorimetrically by UV-spectrophotometry using ferrozine as the coloring agent, and $\mathrm{Fe}(\mathrm{III})$ concentrations were calculated by difference. Table 1 shows the results. Several samples from the filters were ground using agate pellets for bulk analyses by $\mathrm{X}$-ray diffraction.

\section{Analytical results}

Results of the analyses (Table 1) show that $\mathrm{pH}$ increases along the various legs of the drainage. The metal content of the drainage decreases as the $\mathrm{pH}$ increases. At the seep sources, concentrations greatly exceed suggested maximum contamination levels (MCL values; Table 2). Within $80 \mathrm{~m}$ of the seep source concentrations have attenuated to levels approaching those found in Willow Creek upstream of the drainage.

To determine the significance of mixing with background water, species concentrations are plotted in Fig. 3 against $\mathrm{SO}_{4}$, which is taken as a conservative tracer. Mixing lines in this figure represent concentration trends expected through simple dilution of the most $\mathrm{SO}_{4}$-rich water (site 1) by Willow Creek water (site 23). The $\mathrm{SO}_{4}$ concentration of sample 22, the most dilute sample, suggests that mixing ratios reach $15 \mathrm{~kg}$ background water to $1 \mathrm{~kg}$ drainage water. Values that fall above a mixing line reflect addition to solution via mineral dissolution or desorption from mineral surfaces. When values fall below the mixing line, aqueous species have been removed from solution via mineral precipitation or adsorption.

Although $\mathrm{SO}_{4}$ in mine drainage is not necessarily a conservative tracer. $\mathrm{SO}_{4}$ concentrations in this study are sufficiently high compared to $\mathrm{Fe}$ and $\mathrm{Al}$ concentrations that it exhibits conservative behavior. Nordstrom (1982); Chapman et al. (1983) suggest that $\mathrm{SO}_{4}$ is removed from solution via the precipitation of $\mathrm{Al}$ hydroxysulfate phases such as alunite, basaluminite, and possibly also jurbanite. Pecos Mine drainage has a $\mathrm{pH}$ too high for jurbanite stability. Precipitating all of the aluminum in solution as alunite and/or basaluminite results in removal of less than $5 \%$ of the original $\mathrm{SO}_{4}$ concentration; this result is considered to be within experimental and analytical error of $\mathrm{SO}_{4}$ concentration measurements. Species concentrations could

Table 2

National suggested maximum contaminant levels (MCLs) for various elements found in the Pecos Mine contaminated drainage

\begin{tabular}{ll}
\hline Contaminant & MCLs (ppm) \\
\hline $\mathrm{Al}$ & $0.050-0.20$ \\
$\mathrm{~Pb}$ & 0.015 \\
$\mathrm{Fe}$ & 0.3 \\
$\mathrm{Mn}$ & 0.05 \\
$\mathrm{Zn}$ & 5.0 \\
$\mathrm{Cu}$ & 1.3 \\
$\mathrm{SO}_{4}$ & 250 \\
\hline
\end{tabular}



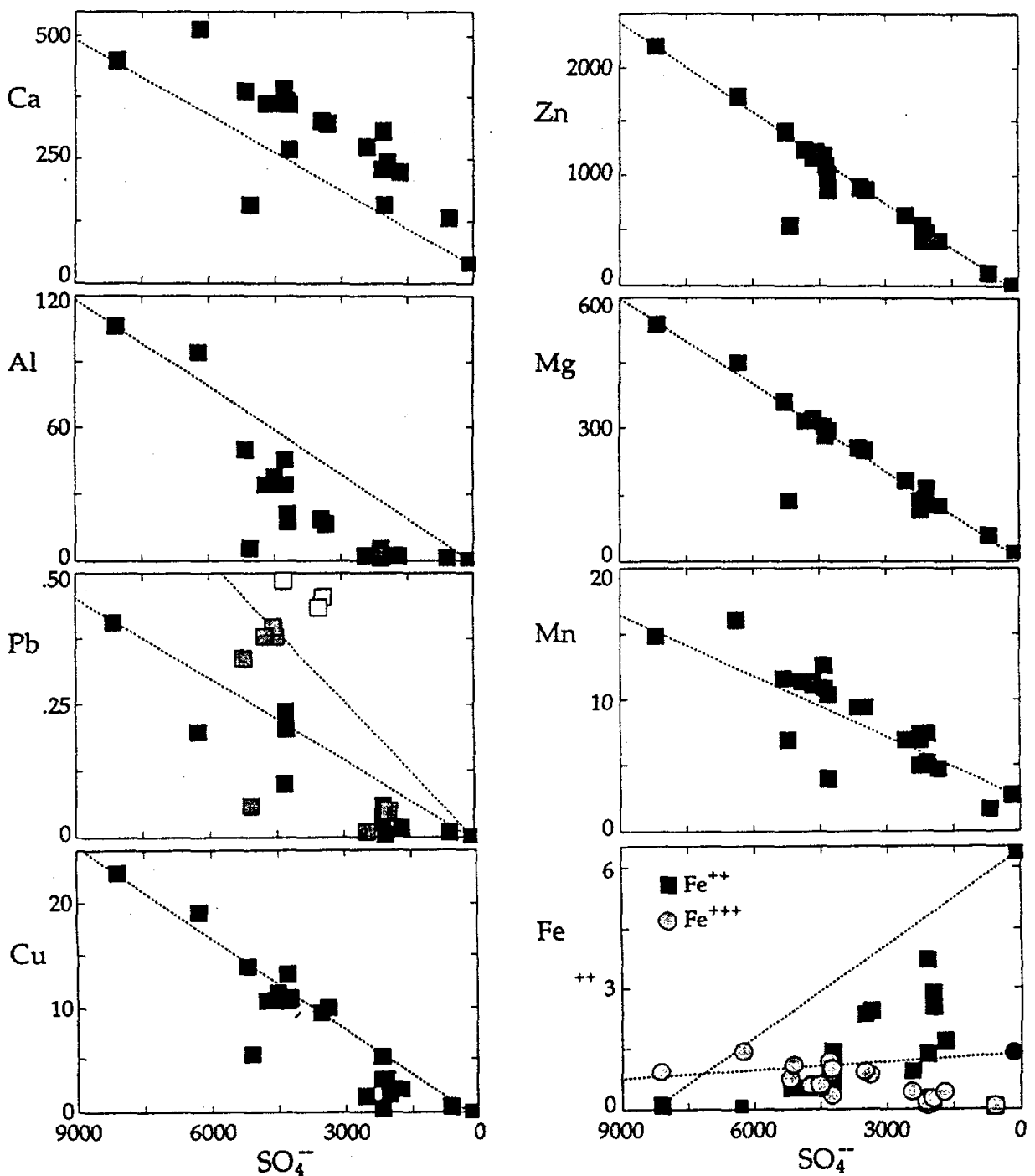

Fig. 3. The dashed line represents concentrations that would result solely from mixing of mine water with background water. Concentrations below this line indicate removal of the aqueous species from solution (e.g. via precipitation), whereas concentrations falling above the line represent an addition to solution, such as mineral dissolution. Black squares are measured concentrations at site 23.

also be plotted against $\mathrm{Cl}^{-}$with qualitatively the same results. However, since $\mathrm{Cl}^{-}$concentrations are two orders of magnitude smaller than $\mathrm{SO}_{4}$ concentrations, they are subject to higher analytical error.

Measured $\mathrm{Ca}$ concentrations are as much as $125 \mathrm{mg} /$ $\mathrm{kg}$ higher than would be expected in the mixed fluid (Fig. 3). Therefore, Ca must have been added to solution, probably by dissolving calcite from the underlying, formation. Conversely, $\mathrm{Al}, \mathrm{Cu}$, and $\mathrm{Pb}$ concentrations fall below the mixing line. These metals likely were removed from solution through precipitation of $\mathrm{OH}, \mathrm{SO}_{4}$, or sulfate phases. Alternatively, they may have sorbed on surfaces of precipitating phases. Iron concentrations also fall below the mixing line; however, the mixing line for $\mathrm{Fe}$ has positive slope as Willow Creek water has higher concentrations of $\mathrm{Fe}$ than the drainage water. Willow Creek flows through an iron-rich swamp north of the drainage. This $\mathrm{Fe}$ is primarily in the reduced state. Zinc, $\mathrm{Mg}$ and $\mathrm{Mn}$ concentrations fall along mixing lines. Neither precipitation nor dissolution reactions affect the concentrations of these metals.

Solids filtered from solution were analyzed by X-ray diffraction. Fig. 4 shows some XRD patterns. These 


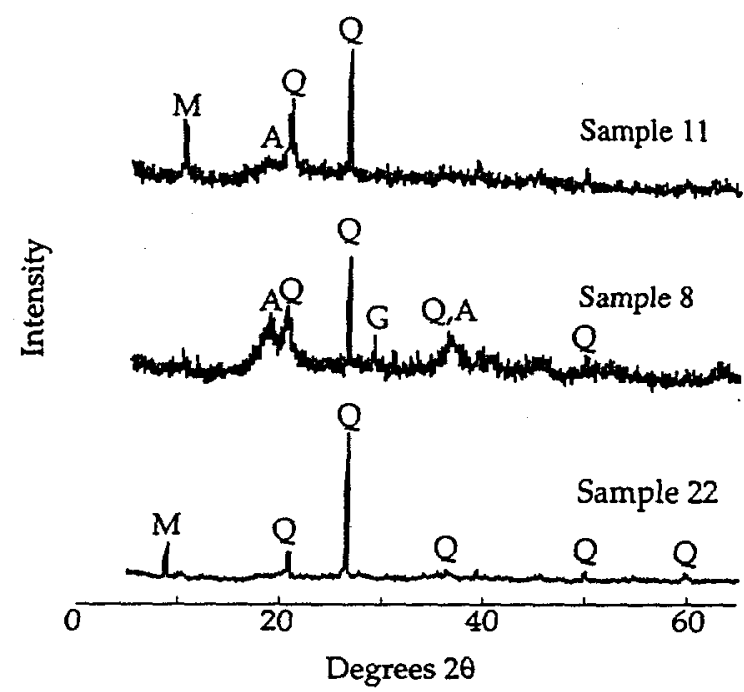

Fig. 4. X-ray diffraction patters from micronized dehydrated field samples. See Fig. $I$ for site locations. $Q=q u a r t z$, $A=$ aluminum hydroxide, $M=$ mica, $G=$ gypsum .

samples show few well defined peaks; reflections from quartz dominate the pattern. Samples 8 and 11 exhibit peaks consistent with Al hydroxide. The broad, low intensity peaks centered around $20^{\circ} 2 \theta$ in samples 8 and 11 are indicative of amorphous or poorly crystalline material, which is typical with acid drainage precipitates (e.g. Nordstrom, 1982; Chapman et al., 1983; Brady et al., 1986). The XRD results indicate the particulate material is a mixture of precipitates from solution such as $\mathrm{Al}$ oxide, and residual phases from dissolving limestone from the underlying formation.

\section{Process modeling}

To describe the geochemical process or processes responsible for the observed trends in $\mathrm{pH}$ and metal content, the authors developed a reaction model using the React program (Bethke, 1998) to predict changes in the chemistry of the evolving drainage. React, a part

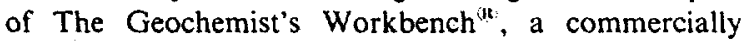
available software package, is designed to simulate reaction processes such as mass transfer, redox reactions, and mixing in geochemical systems. The Lawrence Livermore National Laboratories (Delany and Lundeen, 1989) database of mineral and species equilibrium constants was used. Bethke (1996) describes the basis of the simulations and the numerical solution methods employed.

The authors considered several hypotheses to explain the observed changes in drainage chemistry: that (1) mixing background water into drainage water affected its chemistry, (2) the solution was neutralized as a result of dissolving limestone, and (3) these two processes occurred concurrently. Each of the processes works to raise drainage $\mathrm{pH}$.

For the model, an initial system is taken that consists of $1 \mathrm{~kg}$ of mine drainage water, the chemical composition of which is constrained by analyses of samples from site 1. The fluid is assumed to maintain equilibrium with $\mathrm{O}_{2}$ and $\mathrm{CO}_{2}$ in the atmosphere. Mixing is simulated with background fluids, reaction with limestone, or both processes concurrently, by incrementally changing the system as aliquots of minerals or fluid, or both, are added. The calculation reflects how the system evolves chemically over the course of the reaction process.

In the simulation, adding a neutral water with low metal concentrations to the contaminated drainage increases $\mathrm{pH}$ because the total number of $\mathrm{H}^{+}$ions per kilogram of solution is diluted. In addition, background water contains $\mathrm{HCO}_{3}^{-}$ions that react with acid to form aqueous $\mathrm{CO}_{2}$

$\mathrm{H}^{+}+\mathrm{HCO}_{3}^{-} \rightarrow \mathrm{H}_{2} \mathrm{O}+\mathrm{CO}_{2}(\mathrm{aq})$

some of which may be subsequently lost to the gas phase

$\mathrm{CO}_{2}(\mathrm{aq}) \rightarrow \mathrm{CO}_{2}(\mathrm{~g})$

To simulate the dissolution of limestone, calcite is added to the initial drainage water. As calcite dissolves, $\mathrm{pH}$ increases due to

$$
\underset{\text { Calcite }}{\mathrm{CaCO}_{3}}+2 \mathrm{H}^{+} \rightarrow \mathrm{Ca}^{2+}+\mathrm{H}_{2} \mathrm{O}+\mathrm{CO}_{2}(\mathrm{aq})
$$

producing additional aqueous $\mathrm{CO}_{2}$ that may degas via reaction (2). Later in the reaction, where $\mathrm{pH}$ has increased to above about 6.7 , the reaction

$$
\underset{\text { Calcile }}{\mathrm{CaCO}_{3}}+\mathrm{H}^{+} \rightarrow \mathrm{Ca}^{2+}+\mathrm{HCO}_{3}^{-}
$$

consumes acid.

As acid in the drainage is neutralized, metal concentrations can attenuate in several ways. As $\mathrm{pH}$ increases, metals may precipitate directly, e.g.

$$
\mathrm{Fe}^{3+}+3 \mathrm{H}_{2} \mathrm{O} \rightarrow \underset{\text { Ferric hydraxide }}{\mathrm{Fe}(\mathrm{OH})_{3}}+3 \mathrm{H}^{+}
$$

In addition, precipitates such as ferric hydroxide may scavenge metals from solution through sorption reactions; e.g.

$>\mathrm{FeOH}+\mathrm{Zn}^{2+} \rightarrow>\mathrm{FeOZn}^{+} \mathrm{H}^{+}$

where $>$ FeOH represents a reactive site on the surface 
of the adsorbing mineral ferric hydroxide, and $>\mathrm{FeOZn}^{+}$represents the same site complexed with a $\mathrm{Zn}$ ion. Metal concentrations decrease via these precipitation and adsorption reactions, and, in the case of mixing, by simple dilution.

In the simulations, incremental addition of either Willow Creek water, calcite, or both, proceeds until the system attains a pH equal to that measured in the field downstream from the drainage (site 22). Over the course of the reaction, stable minerals in the LLNL database that are unlikely to precipitate within a short period of time (e.g. hematite)are suppressed from the calculations. This choice favors the precipitation of less stable phases [e.g. ferric hydroxide: $\mathrm{Fe}(\mathrm{OH})_{3}(\mathrm{~s})$ ] Minerals not considered in the calculations are listed in Table 3. Adsorption of metals to hydrous ferric oxides is modeled using the model developed by Dzombak and Morel (1990). Adsorption to Al hydroxides is also modeled using a similar model (Berger, 1999).

\subsection{Mixing}

The chemistry of Willow Creek water from site 23 is used to model mixing observed at the site. The water in Willow Creek upstream of the mine drainage has a $\mathrm{pH}$ of 7.2 and low metal concentrations. Willow Creek has a $\mathrm{pH}$ very similar to that measured downstream from the drainage; to increase drainage $\mathrm{pH}$ to approximately the downstream $\mathrm{pH}$ solely via mixing requires a mixing ratio of at least 200 parts background water to one part drainage water (Fig. 5). Very little mineral mass precipitates over the course of the simulation; as a result, metal concentrations decrease during mixing along simple dilution curves, as shown in Fig. 6. These predicted concentrations fall below the observed concentrations.

Table 3

Minerals in the LLNL database (Delany and Lundeen, 1989) that are not considered in the calculations

Al-bearing minerals:

Fe-bearing minerals:

Mn-bearing minerals:

$\mathrm{Zn}$-bearing minerals: diaspore (AlOOH)

ferrite $\left[(\mathrm{Zn}, \mathrm{Cu}) \mathrm{Fe}_{2} \mathrm{O}_{4}\right]$ goethite $(\mathrm{FeOOH})$

hematite $\left(\mathrm{Fe}_{2} \mathrm{O}_{3}\right)$

birnessite $\left(\mathrm{Mn}_{8} \mathrm{O}_{19} \mathrm{H}_{10}\right)$

bixbyite $\left(\mathrm{Mn}_{2} \mathrm{O}_{3}\right)$

hausmannite $\left(\mathrm{Mn}_{3} \mathrm{O}_{4}\right)$

manganite $(\mathrm{MnOOH})$

pyrolusite $\left(\mathrm{MnO}_{2}\right)$

todorokite $\left(\mathrm{Mn}_{7} \mathrm{O}_{12} \cdot 3 \mathrm{H}_{2} \mathrm{O}\right)$

smithsonite $\left(\mathrm{ZnCO}_{3}\right)$

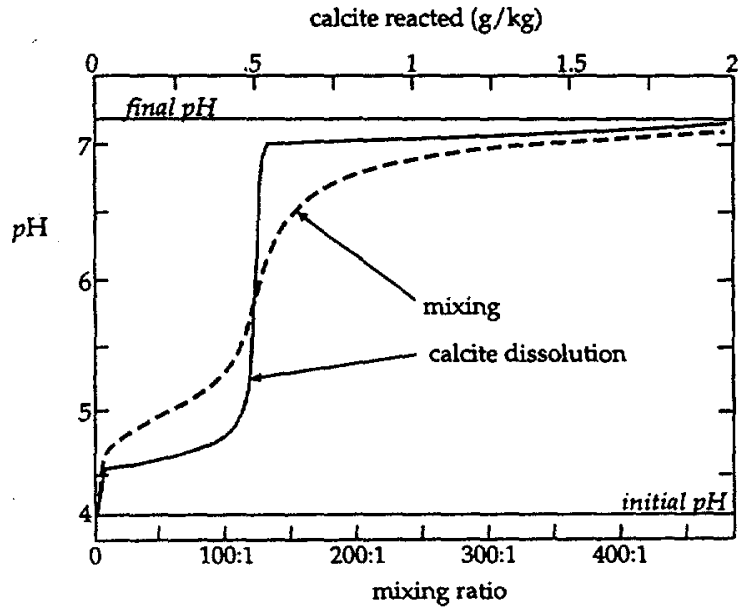

Fig, 5. Modeled change in $\mathrm{pH}$ for $1 \mathrm{~kg}$ of drainage water as a result of dissolution of calcite from limestone in the underlying bedrock (solid line), and mixing with Willow Creek water (dashed line).

\subsection{Reaction with carbonate rocks}

To evaluate the consequences of reaction with limestone that underlies the waste rock pile, calcite was reacted into the original drainage. The model predicts that $\mathrm{pH}$ increased due to reactions 3 and 4, as shown in Fig. 5. In the process of increasing $\mathrm{pH}$ to the measured downstream $\mathrm{pH}$, almost $3 \mathrm{~g}$ of calcite dissolved into $1 \mathrm{~kg}$ of drainage water. The decreasing $\mathrm{H}^{+}$ ion concentration causes a number of mineral phases to precipitate (Fig. 7), via the following:

$$
\begin{aligned}
& \mathrm{Al}^{3+}+3 \mathrm{H}_{2} \mathrm{O} \rightarrow 3 \mathrm{H}^{+}+\underset{\text { Aluminum hydroxide }}{\mathrm{Al}(\mathrm{OH})_{3}} \\
& \mathrm{Cu}^{2+}+\mathrm{H}_{2} \mathrm{O} \rightarrow 2 \mathrm{H}^{+}+\underset{\text { Tenorite }}{\mathrm{CuO}} \\
& \mathrm{Fe}^{3+}+3 \mathrm{H}_{2} \mathrm{O} \rightarrow 3 \mathrm{H}^{+}+\underset{\text { Ferric hydroxide }}{\mathrm{Fe}(\mathrm{OH})_{3}} \\
& 3 \mathrm{Al}^{3+}+\mathrm{K}^{+}+2 \mathrm{SO}_{4}^{2-}+6 \mathrm{H}_{2} \mathrm{O} \rightarrow 6 \mathrm{H}^{+} \\
& +\mathrm{KAl}_{3}(\mathrm{OH})_{6}\left(\mathrm{SO}_{4}\right)_{2} \\
& \text { Alunite } \\
& 3 \mathrm{Fe}^{3+}+\mathrm{Na}^{+}+2 \mathrm{SO}_{4}^{2-}+6 \mathrm{H}_{2} \mathrm{O} \rightarrow 6 \mathrm{H}^{+} \\
& +\mathrm{NaFe}_{3}(\mathrm{OH})_{6}\left(\mathrm{SO}_{4}\right)_{2}
\end{aligned}
$$



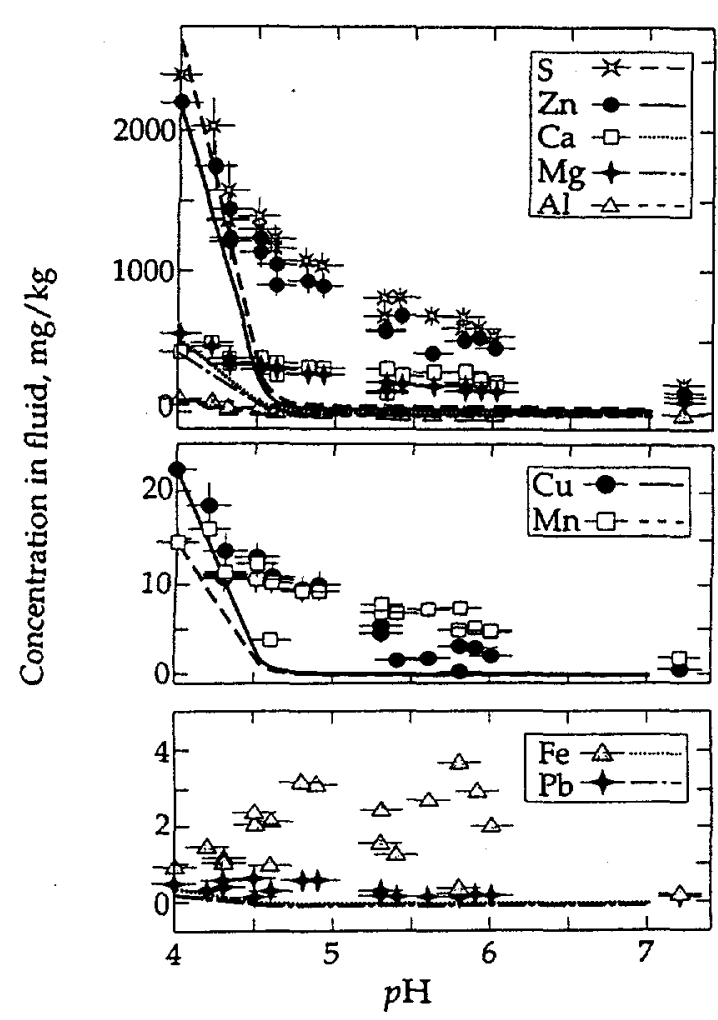

Fig. 6. Predicted concentrations (lines) of major aqueous species as $\mathrm{pH}$ increases due to mixing with Willow Creek water. Measured concentrations are plotted as points verses $\mathrm{pH}$ measured in the field.

$$
\begin{aligned}
& \mathrm{Zn}^{2+}+\mathrm{HCO}_{3}^{-} \rightarrow \mathrm{H}^{+}+\underset{\text { Smithsonite }}{\mathrm{ZnCO}_{3}} \\
& \mathrm{~Pb}^{2+}+\mathrm{HCO}_{3}^{-} \rightarrow \mathrm{H}^{+}+\underset{\text { Cerussite }}{\mathrm{PbCO}_{3}}
\end{aligned}
$$

In addition, gypsum precipitates

$\mathrm{Ca}^{2+}+\mathrm{SO}_{4}^{2-}+2 \mathrm{H}_{2} \mathrm{O} \rightarrow \underset{\text { Gypsum }}{\mathrm{CaSO}_{4} \cdot 2 \mathrm{H}_{2} \mathrm{O}}$

due to a common ion effect driven by the addition of $\mathrm{Ca}$ to solution through the dissolution of calcite.

These reactions remove metal species from solution. Fig. 8 shows how dissolved concentrations attenuate in the simulation. Zinc, $\mathrm{S}, \mathrm{Al}, \mathrm{Cu}, \mathrm{Fe}$ and $\mathrm{Pb}$ attenuate abruptly at the onset of precipitation. Magnesium and $\mathrm{Mn}$ concentrations remain high over the course of the reaction. Calcium concentrations increase as calcite dissolves into solution (Fig. 8).

\subsection{Combined pathway}

As discussed previously, observations at the site suggest that over the initial stretches of the drainage, rock dissolution and fluid mixing between drainage and background water occur concurrently. In Fig. 3, $\mathrm{Ca}$ concentrations deviate above the pure mixing line by $80-125 \mathrm{mg} / \mathrm{kg}$. It is assumed that calcite dissolution accounts for the addition of $\mathrm{Ca}$. To reproduce the extent of dilution suggested by the observed decrease in $\mathrm{SO}_{4}$ concentration, we $\mathrm{mix} 15 \mathrm{~kg}$ of background water into one kilogram of drainage fluid. The fluid's $\mathrm{Ca}$ content in excess of that expected during conservative mixing depends on the amount of calcite that dissolves, as shown in Fig. 9. The general trend of calcium concentration can be explained well by a reaction process in which about $250 \mathrm{mg}$ of $\mathrm{Ca}$ (per $\mathrm{kg}$ of drainage fluid) dissolve over the initial portion of the mixing process, or concurrent with mixing ratios of up to about $3 \mathrm{~kg}$ background water to $1 \mathrm{~kg}$ drainage water. The $250 \mathrm{mg}$ of $\mathrm{Ca}$ is equivalent to $624 \mathrm{mg}$ of calcite. The calcite dissolves completely and no further calcite is added during subsequent mixing. Fig. 9 shows the pathway taken in such a process.

Dissolution of calcite and mixing with background water drives an increase in the $\mathrm{pH}$ via reactions 1,3 and 4. Most of the $\mathrm{CO}_{2}$ produced is subsequently lost to the gas phase. The increase in $\mathrm{pH}$ drives precipitation of Al hydroxide, tenorite, $F e(I I I)$ hydroxide, jarosite, and alunite, via reactions 7-11, as shown in Fig. 10. Fig. 11 shows the predicted behavior of aqueous species concentrations compared to measured drainage concentrations. In this simulation, predicted concentrations match the observed values better than in the previous two simulations.

\section{Discussion}

Results of this study show the chemical evolution of drainage from the Pecos Mine can be explained by the combined effects of calcite dissolution and mixing with background water. Neither dissolution nor mixing alone, however, can explain trends in chemical composition as the drainage flows from the seeps toward the Pecos River. Using the constraints on Ca provided by field data, a model that combines dissolution and mixing predicts an attenuation of aqueous species concentrations that more closely matches concentrations observed in the field (Fig. 11) than either mixing or calcite dissolution alone (Figs. 6 and 8).

In the combined model, calcite dissolution and mixing together increase $\mathrm{pH}$ to a value of 6 . Continued mixing alone increases $\mathrm{pH}$ to a value of 7.2. Aluminum, $\mathrm{Cu}$ and $\mathrm{Fe}$ precipitate directly from solution. This prediction agrees with observations made above. that concentrations of these elements fall below conservative mixing lines (Fig, 3). Moreover, most of the $\mathrm{Cu}$ 


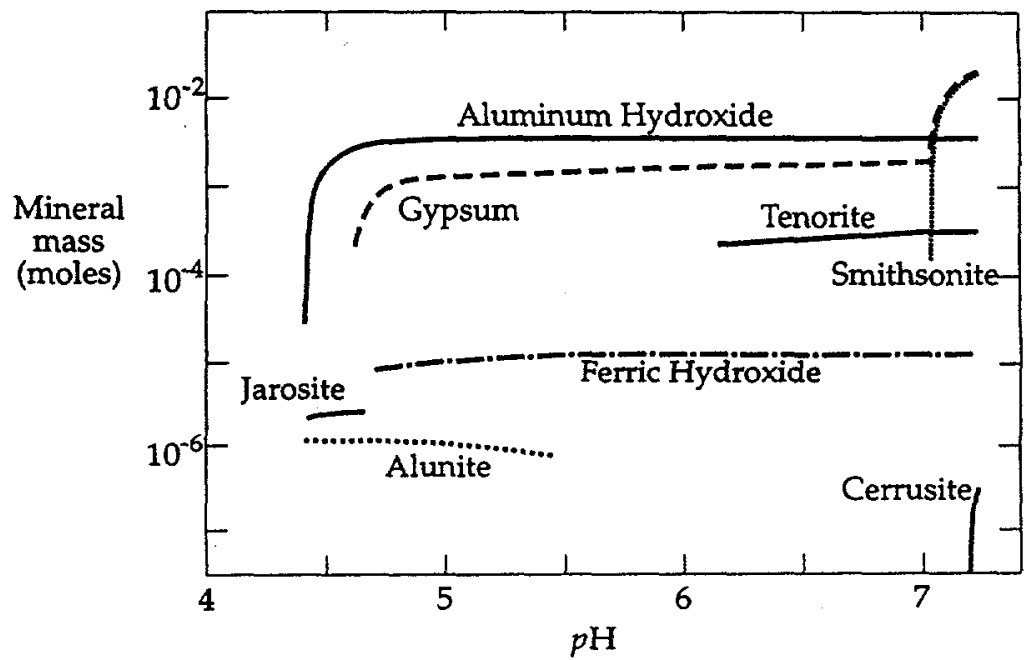

Fig. 7. Predicted cumulative mineral assemblage precipitated as $\mathrm{pH}$ increases as a result of calcite dissolving into one $\mathrm{kg}$ of drainage water.

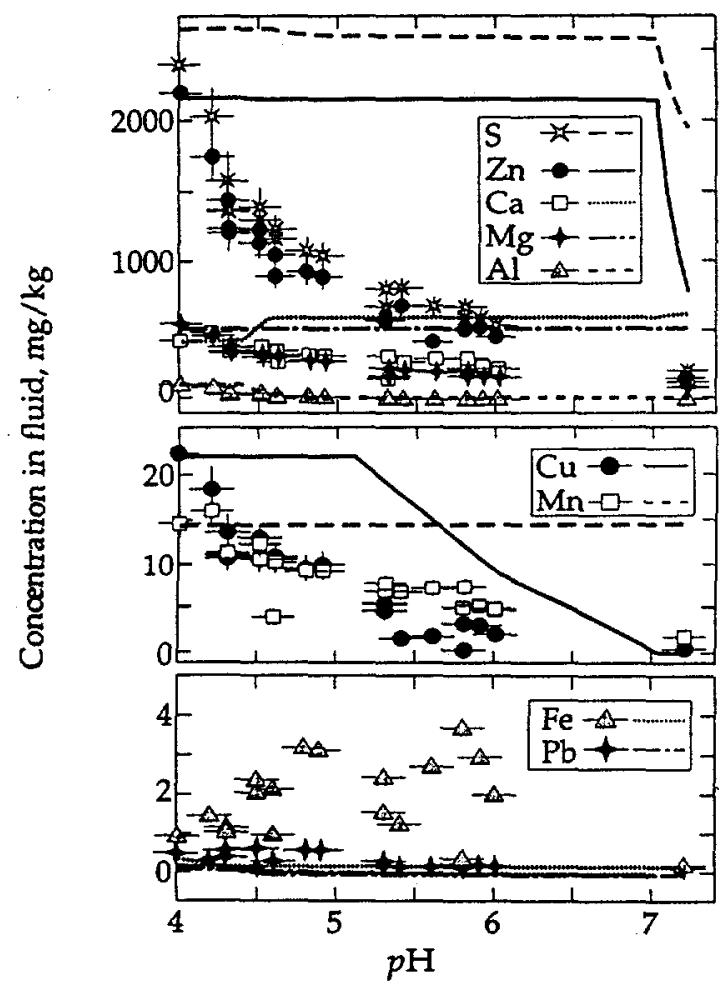

Fig. 8. Predicted concentrations (lines) of major aqueous species as $\mathrm{pH}$ increases due to dissolution of calcite. Measured concentrations are plotted as points verses $\mathrm{pH}$ measured in the field. concentrations that depart from the mixing line do so at later stages of the mixing process, which is consistent with the model prediction of tenorite precipitation. In the calculation, $\mathrm{Zn}$ and $\mathrm{Mg}$ attenuate through simple mixing, also consistent with data in Fig. 3. The model predicts $\mathrm{Mn}$ attenuation through simple mixing when precipitation of oxidized $\mathrm{Mn}$ minerals are excluded (Table 2). Manganese oxidation is $\mathrm{pH}$ dependent, and kinetically inhibited at $\mathrm{pHs}$ observed in the field (Stumm, 1981).

Adsorption as a potential metal scavenger does not play a significant role in metal attenuation. Ferric hydroxides have a high affinity for aqueous metal species; however this phase does not precipitate in sufficient quantities to affect the aqueous concentrations of scavengeable metals. Aluminum hydroxide precipitates in greater quantities; however, it has a much lower site density than hydrous $\mathrm{Fe}(\mathrm{III})$ oxide (Anderson and Benjamin, 1990). Aluminum hydroxide preferentially scavenges $\mathrm{Pb}$ from solution such that up to $10 \%$ of aqueous $\mathrm{Pb}$ is adsorbed on hydroxide surfaces. Aqueous metal concentrations attenuate primarily by direct precipitation of minerals phases, or via simple dilution. Although these mineral phases are likely colloidal upon precipitation, wetland vegetation downstream from the site trap such particles (Stoller, 1996), and any metal transport downstream is likely to be primarily due to bedload transport (McLemore et al., 1993).

Predicted Fe concentrations (Fig. 11) do not show particularly good agreement between the predicted and observed values. Iron concentrations in the Pecos Mine Operable Unit drainage are fairly low compared to typical acid drainages (Smith et al., 1994). Because the 


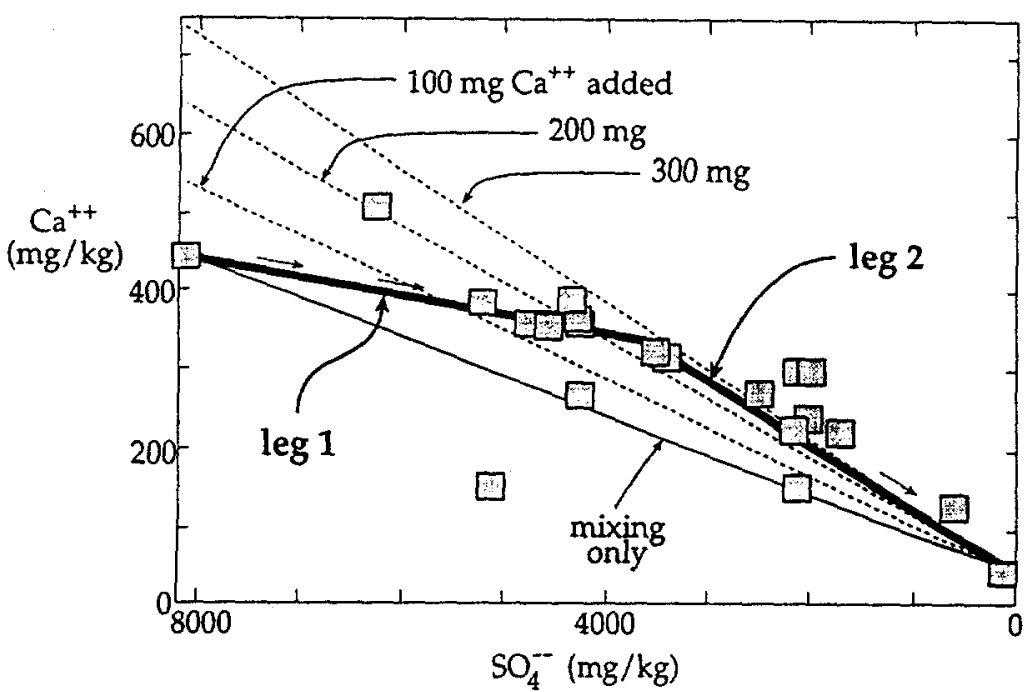

Fig. 9. Trend in Ca concentration predicted by combined reaction pathway. Dashed lines show mixing lines for an initial fuid containing progressively more $C$ a. Symbols show measured $C$ a concentrations from Fig. 3. In leg 1 of the simulation (heavy line), 2.5 $\mathrm{kg}$ of background water and $250 \mathrm{mg}$ of $\mathrm{Ca}$ are added to solution. In leg 2, the remaining $12.5 \mathrm{~kg}$ of background water is added.

background water from Willow Creek has higher $\mathrm{Fe}$ concentrations (of primarily reduced $\mathrm{Fe}$ ) than any of the drainage samples, mixing represents an addition of $\mathrm{Fe}$ to the drainage. Water flowing downstream into the mine drainage may add $\mathrm{Fe}$ to drainage water more rapidly than $\mathrm{Fe}$ oxidizes and precipitates from solution.

If mixing alone is considered in the calculation, attenuation along simple mixing curves occurs earlier than is observed in the field (Fig. 6). The largest discre- pancies in this case are between measured and calculated concentrations of $\mathrm{Zn}, \mathrm{Cu}$ and $\mathrm{Ca}$. In a model that accounts for calcite dissolution alone, metal concentrations attenuate rapidly with the onset of solid precipitation. Metal attenuation observed in the field is continuous rather than abrupt; therefore, with the exception of $\mathrm{Fe}$ and $\mathrm{Ca}$, this model overestimates metal concentration over most of the reaction path (Fig. 8). The model's prediction of $\mathrm{Ca}$ concentration is most striking, as predicted $\mathrm{Ca}$ contents increase along

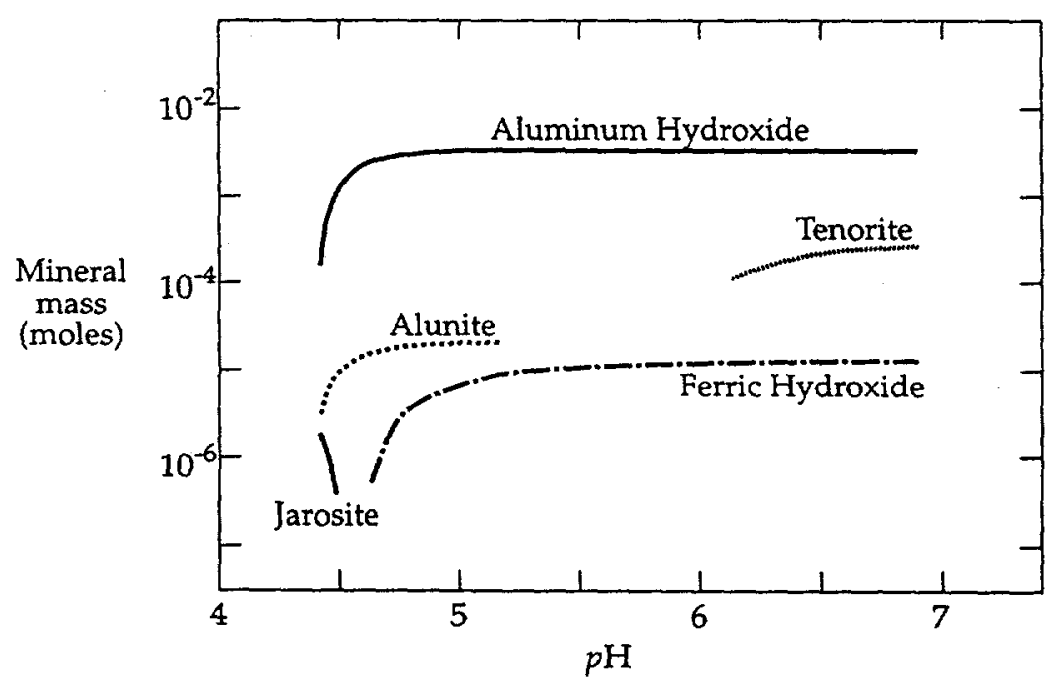

Fig. 10. Predicted mineral assemblage as $\mathrm{pH}$ increases due to concurrent mixing with Willow Creek water and calcite dissolution. 


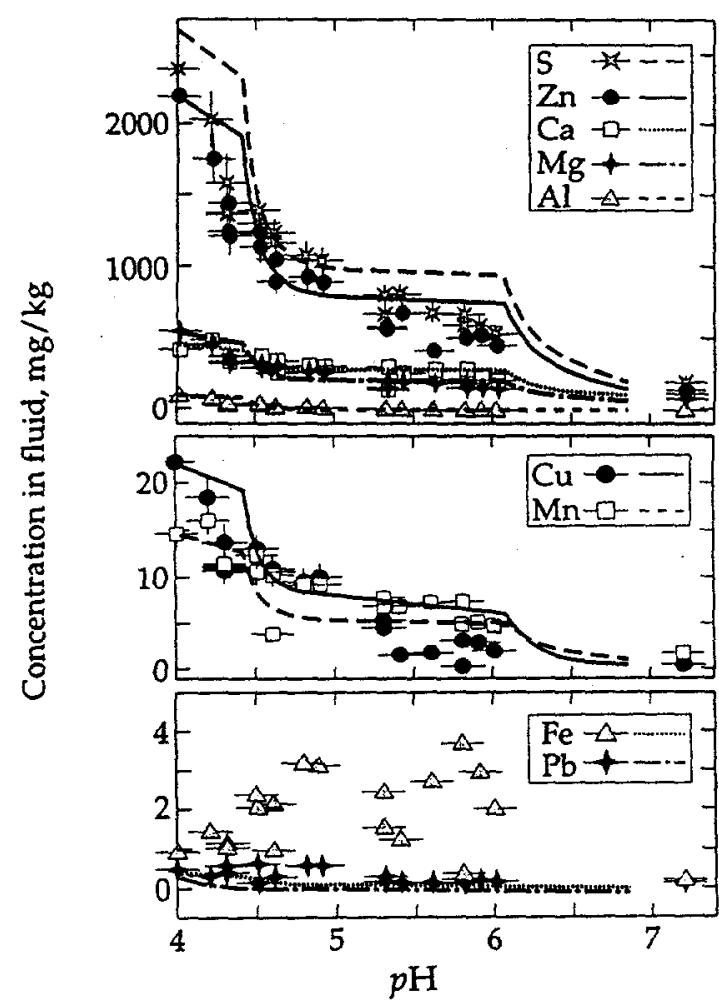

Fig. 11. Predicted concentrations (lines) of major aqueous species as drainage $\mathrm{pH}$ increases due to concurrent mixing with Willow Creek water and calcite dissolution. Measured concentrations are plotted as points verses $\mathrm{pH}$ measured in the field.

the drainage path whereas measured $\mathrm{Ca}$ concentrations decrease. The dissolution model adds $\mathrm{Ca}$ to the system through calcite dissolution but provides no pathway for lowering $\mathrm{Ca}$ concentration.

\section{Conclusions}

This study shows that the primary geochemical control governing the acid drainage chemistry at the Pecos Mine Operable Unit cannot be the result of one but must be at least two processes including mineral buffering and dilution by mixing with ambient waters. Geochemical modeling is used to demonstrate the relative importance of $\mathrm{CaCO}_{3}$ dissolution and mixing with more dilute waters on the attenuation of both acidity and metal contamination. Drainage chemistry is best modeled by mixing $15 \mathrm{~kg}$ ambient water into $1 \mathrm{~kg}$ mine water over the course of the flow path, with concurrent dissolution of about $0.6 \mathrm{~g}$ of calcite over the initial portion of the reaclion. Calcite dissolution is most important near the seeps; downstream, mixing seems to operate alone.

\section{Acknowledgements}

The authors would like to thank the Roger Adams Laboratory at the University of Illinois, M. Machesky, and the Illinois State Water Survey for assistance with sample analyses, D. Finkelstein, for assistance with solid sample analyses, $M$. Tidrick, for assistance in fieldwork, and D. Banks, P. Younger and $M$. Brudzinski for their helpful reviews of the manuscript.

\section{References}

Anderson, P.R., Benjamin. M.M., 1990. Modeling adsorption in aluminum-iron binary oxide suspensions. Environ. Sci. Tech. 24, 1586-1592.

Berger, A.C., 1999. Controls on heavy metal mobility at the Pecos Mine Operable Unit. Ph.D. thesis, Dept. Geol. Univ. of III.

Bethke, C.M., 1996. Geochemical Reaction Modeling. Oxford.

Bethke, C.M., 1998. The Geochemist's Workbench" Users Guide. University of Illinois.

Brady, K.S., Bigham, J.M., Jaynes. W.F., Logan. T.J., 1986. Influence of sulfate on Fe-oxide formation: comparisons with a stream receiving acid mine drainage. Clays Clay Mineral 34, 266-274.

Chapman, B.M., Jones, D.R., Jung. R.F., 1983. Processes controlling metal ion attenuation in acid mine drainage streams. Geochim. Cosmochim. Acta 47, 1957-1973.

Delany J.M., Lundeen S.R., 1989. The LLNL thermochemical database. Lawrence Livermore National Laboratory Rep. UCRL-21658.

Dzombak. D.A., Morel, F.M.M., 1990. Surface complexation modeling: Hydrous Ferric Oxide. John Wiley \& Sons.

Förstner, U., Wittman, G.T.W., 1981. Metal pollution in the aquatic environment. Springer-Verlag.

Kelly, M.. 1988. Mining and the freshwater environment. Elsevier.

Kimball, B.A., Broshears, R.E., McKnight, D.M., Bencala, K.E., 1994. Effects of instream pH modification on transport of sulfide-oxidation products. In: Environmental Geochemistry of Sulfide Oxidation. American Chemical Society, pp. 224-243.

Krieger, P., 1932. Geology of the zinc-lead deposit at Pecos, New Mexico. Econ. Geol. 27, 344-364.

McLemore, V.T., Brandvold, L.A., Brandvold, D.K., 1993. A reconnaissance study of mercury and base metal concentrations in water, and stream-and lake-sediment samples along the Pecos River. Eastern New Mexico. New Mexico Geal. Soc. Guidebook, 44th Field Conference, 339-351.

Nordstrom, D.K., 1982. The effect of sulfate on aluminum concentrations in natural waters: some stability relations in the system $\mathrm{Al}_{2} \mathrm{O}_{3}-\mathrm{SO}_{3}-\mathrm{H}_{2} \mathrm{O}$ at $298 \mathrm{~K}$. Geochim. Cosmochim. Acta 46, 681-692. 
Plumlee, G.S., Smith, K.S., Ficklin, W.H., Briggs, P.H., 1992. Geological and geochemical controls on the composition of mine drainages and natural drainages in mineralized areas. In: Proc. 7th Int. Symp. Water-Rock Interactions, pp. 419-422.

Riesmeyer, W.D., Robertson, J.M., 1979. Precambrian geology and ore deposits of the Pecos Mine, San Miguel County, New Mexico. NM Geol. Soc. Guidebook, 30th Field Conference.

Smith, K.S., Plumlee, G.S., Ficklin, W.H., 1994. Predicting water contamination from metal mines and mining wastes. USGS Open File Report 94-264.

Stoller (The S.M. Stoller Corporation), 1993. Background Report, Tererro Mine Site, San Miguel County, New
Mexico, prepared for AMAX Resource Conservation Company, Golden, CO.

Stoller (The S.M. Stoller Corporation), 1994. Remedial Investigation Proposal for the Pecos Mine Operable Unit (Tererro Mine Site), prepared for Cyprus Amax Minerals Company, Englewood, CO.

Stoller (The S.M. Stoller Corporation), 1996. Remedial Investigation Report, prepared for Cyprus Amax Minerals Company, Englewood, CO.

Strömberg, B., Banwart, S., 1994. Kinetic modeling of geochemical processes at the Aitik mining waste rock site in northern Sweden. Appl. Geochem. 9, 583-594.

Stumm, W., 1981. Aquatic Chemistry, An Introduction Emphasizing Chemical Equilibria in Natural Waters. John Wiley \& Sons. 